University of Minnesota Morris Digital Well

University of Minnesota Morris Digital Well

$12-4-2017$

\title{
Putin and Trilateral Economic Cooperation between Moscow, Seoul, and Pyongyang: Motivation, Feasibility, and Korean Peace Process
}

Seung-Ho Joo

University of Minnesota, Morris, joos@morris.umn.edu

Yune Lee

Incheon National University

Follow this and additional works at: https://digitalcommons.morris.umn.edu/polisci

Part of the International Relations Commons

\section{Recommended Citation}

Joo, Seung-Ho and Lee, Yune, "Putin and Trilateral Economic Cooperation between Moscow, Seoul, and Pyongyang: Motivation, Feasibility, and Korean Peace Process" (2017). Political Science Publications. 1. https://digitalcommons.morris.umn.edu/polisci/1

This Article is brought to you for free and open access by the Faculty and Staff Scholarship at University of Minnesota Morris Digital Well. It has been accepted for inclusion in Political Science Publications by an authorized administrator of University of Minnesota Morris Digital Well. For more information, please contact skulann@morris.umn.edu. 


\section{Putin and Trilateral Economic Cooperation between Moscow, Seoul, and Pyongyang: Motivation, Feasibility, and Korean Peace Process}

Since 2000 President Vladimir Putin of Russia has persistently pushed for trilateral economic projects between Moscow, Seoul, and Pyongyang, especially in the fields of energy (oil, gas, and electricity) and transportation (railroad). The Kremlin has long maintained that its proposed trilateral projects would not only be economically beneficial to all and but also pave the road to inter-Korean reconciliation and peaceful unification. For years, trilateral economic projects had not gone beyond consultations and unfulfilled promises. Year 2013 witnessed two critical developments in this regard. In 2013, Russia completed renovating the $54 \mathrm{Km}$ railway route linking Russia’s Khasan and North Korea’s Rajin ${ }^{1}$ as the first step to Putin’s pet project known as the Iron Silk Road (hereafter ISR) linking the Trans-Siberian Railway to the Trans-Korean Railway. In the following year, Russia finished modernizing pier 3 of the Rajin port near the Russian border and shipped the first batch of Siberian coal from Rajin to Pohang of South Korea. The pilot project demonstrated that trilateral economic cooperation between Moscow, Seoul, and Pyongyang might be within reach.

In October 2013, then President Park Geun-Hye of South Korea announced the ‘Eurasia Initiative’ that would link energy and logistics infrastructure across the Eurasian continent. Park’s initiative included the creation of 'Silk Road Express' that would connect rail and road networks from Korea's Busan to Europe, the development of the Arctic Sea route to Europe, and the cooperation in the energy field (electricity grids, gas and oil pipelines, and Siberia's petroleum and gas development). She postulated that her initiative in energy and logistics would facilitate a free trade zone across Eurasia and the formation of the 'Eurasian economic bloc' similar to the European Union (EU) (Choi 2013). In fact, Park’s Eurasian initiative, especially those concerning energy and transportation, closely resembles Putin's trilateral cooperation proposals. In November 2013, Putin paid an official visit to Seoul for summit talks with Park Geun-Hye and the two leaders agreed to cooperate for trilateral projects including North Korea in rail transport, electricity, and gas supply.

Putin's proposed trilateral economic projects and Park’s Eurasian initiative overlap substantially and share commonalities. It appeared at the time that trilateral economic cooperation among Moscow, Seoul, and Pyongyang

\footnotetext{
${ }^{1}$ Rajin is now a district of North Korea's Special City Rason. Rason is short for Rajin-Sonbong, two formerly separate cities. In this article, Rajin and Rason will be used synonymously.
} 
was finally gaining momentum and its prospects were brighter than ever. Nevertheless, the proposed projects failed to take off and were put on the back burner by early 2016. Deepening nuclear crisis on the Korean peninsula especially after President Donald Trump’s inauguration in February 2017 and the impeachment of President Park in March 2017 make the realisation of the ambitious multinational economic projects unlikely in the near term. Given its potential economic benefits and political implications for Korean peace process, mutual interest in trilateral economic cooperation, however, is likely to be rekindled in the future as political conditions in and economic needs of the countries involved, and international atmosphere shift.

This article addresses three questions regarding Putin’s proposed trilateral economic projects. What motivates Putin’s push for the trilateral economic projects? Would the projects bring benefits to all the three countries? Would the projects facilitate Korean peace process? The authors argue that Putin's trilateral economic proposals are part of Russia's quest for power and search for a multipolar world order, and should be understood from the theoretical framework of 'structural realism'. The research finds that the projects are not feasible due to North Korea's nuclear crisis and economic uncertainties. The research concludes that the projects are not likely to be implemented without North Korea's leadership change. The article will begin with a discussion of structural realism which will be followed by an examination of the motivation behind Russia’s Korea policy as relate to the trilateral economic cooperation. It will then examine the evolution and the status of the proposed economic projects in the areas of ISR, gas pipelines, and electric gridlines. Finally, it will analyse the projects' feasibility and implications for the Korean peace process.

\section{Structural Realism}

Kenneth Waltz (Waltz 1979) in his seminal work, Theory of International Politics, presented structural realism (hereafter SR). Waltz's SR begins from the premise that the international system in which states find themselves is in a state of anarchy and with no supra-national authority to regulate states' external behavior and inter-state interactions. In the anarchic international system, states’ primary motivation is survival and every state has to rely on self-help to safeguard this vital interest. States are the main units of the international system and are “distinguished primarily by their greater or lesser capabilities for performing similar tasks.” (Waltz 1979, pp. 80) He maintains that the structure of the international system limits cooperation among states in two ways. First 'the condition of insecurity—at the least, the uncertainty of each about the other's future intentions and actions' prevents 
cooperation. Second, a state is reluctant to cooperate with other states in fear of becoming dependent on them. (Waltz 1979, p. 106) In a self-help system, Waltz continues, “considerations of security subordinate economic gain to political interest."(Waltz 1979, p. 107)

SR posits that the structure of the international system (the number of major actors and their respective capabilities) shapes the patterns of states' interactions. Waltz postulates that 'a system is composed of a structure and of interacting units' and defines a structure as ‘the arrangement of its parts' (Waltz, 1979, p. 79). To define a structure we need to look at 'how they [units] stand in relation to one another (how they are arranged or positioned)'(Waltz, 1979, p. 80), he explains. He maintains that the structure of the international system limits cooperation among states. He points to the fact that states in an international system exhibit similar foreign policy behavior despite their different political systems and contrasting ideologies. He points out that the US and the Soviet Union during the Cold War showed remarkably similar patterns of behavior despite different socio-economic systems and values. Waltz in his theory underlines the importance of the "systemic constraints" on states' behavior. To put it differently, the structure of the international system largely determines and constrains states’ behavior. In his article, 'Structural Realism after the Cold War', Waltz reiterates this point: 'Structural change affects the behavior of states and the outcomes their interactions produce. It does not break the essential continuity of international politics. The transformation of international politics alone could do that. Transformation, however, awaits the day when the international system is no longer populated by states that have to help themselves.' (Waltz, 2000, p. 39)

In his article published shortly after the collapse of the Cold War, Waltz predicted that the US-dominant, uni-polar system of the time would be replaced by a multi-polar one because 'units in a self-help system engage in balancing behavior'. (Waltz, 1993, p. 73) He further states that "hegemony leads to balance .... Over time, unbalances power will be checked by the response of the weaker who will, rightly or not, feel put upon.' (Waltz, 1993, p. 79) In short, Waltz postulates that as long as the international system remains anarchic, states will seek to ensure their security and survival while engaging in balancing act and opposing hegemony. He also predicts that major powers such as China, Japan, German, and Russia will strive to replace the unipolar system with a multipolar one. Waltz notes that weaker states behave differently from stronger states since weaker states 'bandwagon' (to ally with the stronger state) rather than 'balance’ (to ally against the stronger state). (Waltz 1993, p. 126.) 
His predictions, indeed, have been borne out in Russia's policies and behavior in the post-Cold War era. In the wake of Soviet empire's collapse, Russia under Boris Yeltsin followed a liberal, pro-Western foreign policy line. Russia, however, quickly discarded this foreign policy orientation in favor of a neutral, independent foreign policy characterized by pragmatism and realpolitik. Yeltsin's brief experiment with the pro-Western foreign policy for 2-3 years was an aberration rather than the norm. Russia's foreign policy line with Putin at the helm has been steady asserting its interests and standing up to the U.S. on a range of issues (the U.S. national missile defense program, NATO's eastward expansion, North Korea's nuclear crisis, etc.) and in numerous conflict zones (Georgia, Syria, Crimea and eastern Ukraine, etc.). Even President Obama’s attempt at 'Russian reset' in 2009 failed to shift the course of Russia’s foreign policy direction. (Cohen, 2011; Craig, 2012) Putin’s Russia has been in search of its rightful place among the world's great powers (Mankoff, 2009). At the top of Russia foreign policy goals are the creation of a multipolar order, balance between the East and the West, and multilateral approach to peace and security (Russian Ministry of Foreign Affairs, 2008). It is noteworthy that Russia lists the goal of replacing the USdominated unipolar world order with a multipolar one as its top priority. This clearly is a balancing act against US hegemony.

\section{Motivation}

Russia’s Korea policy has direct bearings on US hegemony and Russia’s penchant to undermine it. Korea’s value in Russia's strategic calculus lies in U.S. involvement in and influence over the Korean peninsula. Russia seeks to prevent any external power, especially the U.S., from ascending to a predominant position throughout the Korean peninsula (thus posing a threat to its Far Eastern region), enhance its stature as a responsible stake holder in dealing with the Korean question, and expand its economic ties with the two Koreas for the development of its Far Eastern provinces.

Upon assuming power in 2000, Putin has tirelessly and patiently advocated trilateral economic cooperation involving Moscow, Seoul, and Pyongyang, while projecting its image as a peacemaker, a voice of reason, and a counterbalance on U.S. military adventurism. The Kremlin intends to take advantage of its abundant energy resources in the Far East and its geographic location straddling the East and the West to strengthen its power position vis-à-vis the U.S. Trilateral economic projects as envisioned by Putin are expected to put both Koreas into 
Russia’s "economic" sphere of influence while serve as an impetus for developing Russian far east and integrating Russia's economy into Northeast Asia's dynamic economies. Successful implementation of the trilateral economic projects should undermine the dominant position of the U.S. in and around Korea. In this sense, Russia’s Korea policy in general and its projects for the trilateral economic cooperation reflects its desire to weaken U.S. hegemony and construct a multipolar world order in which Russia becomes an important player.

Since the mid-1990s, the Kremlin has opposed the unipolar world dominated by the US and favored a multi-polar world. Russia's policy on North Korea's nuclear issue also shows that its primary concern is to oppose U.S. hegemony rather than nuclear nonproliferation in Korea. In response to North Korea's nuclear provocations and bellicose outbursts, Russia has refused to cooperate with the U.S. at UN Security Council sessions or outside the UN forum to effect North Korea’s denuclearization. In unequivocal terms, Russia has repeatedly stated its policy of not accepting North Korea as a nuclear power. By the same token, Russia advocates peace and stability on the Korean peninsula, and sternly opposes any military action that might spark a second Korean war. Russia would rather live with nuclear-armed North Korea for the time being than follow the US lead in ratcheting up pressures on or take forceful action against North Korea. Russia’s policy on North Korea’s nuclear bombs confirms its primary interest of opposing the U.S. as the hegemonic power.

In the following sections, Putin’s proposed projects of trilateral economic cooperation will be discussed, focusing on the iron silk road, gas pipelines, and electric gridlines.

\section{Iron Silk Road}

The Iron Silk Road (ISR) plan of connecting European Russia to Northeast Asia by linking the TransSiberian Railway (TSR) with the Trans-Korean Railway (TKR) has been one of Putin's pet ideas. Soon after his inauguration as Russian President in 2000, Putin began to pitch for ISR. Putin first broached ISR during his first summit meeting with Kim Jong-il in Pyongyang in July 2000, and Kim responded favourably to the idea. As early as June 1994, Kim Il Sung, North Korea's founding leader and Kim Jong-il’s father, had expressed a strong interest in similar multinational railroad projects linking TSR to TKR with a view to collecting transit fees. Since such a project was Kim Il Sung’s Yuhun Sahup (project of the deceased leader), Kim Jong-il was favourably inclined 
toward Putin's suggestion. ${ }^{2}$ Putin also discussed ISR and other trilateral economic projects, involving Russia and the two Koreas, when he met with President Kim Dae-jung of South Korea on the sidelines of the 2000 UN Millennium Summit held in September 2000 in New York, and the two leaders agreed on ISR. Earlier in June 2000, Kim DaeJung and Kim Jong-Il, the leaders of South and North Korea, agreed at their first ever inter-Korean summit meeting in Pyongyang to re-link inter-Korean railways that had been severed by the division of the Korean peninsula in 1945. When Putin and Kim Jong-il held their second summit meeting in Moscow in July 2001, the two leaders reaffirmed their intent to pursue ISR. The 2001 DPRK-Russia Moscow Declaration adopted at the end of their talk stated that 'both sides declared that the work of linking the DPRK-Russia railways has entered the full-scale stage, committing themselves to exert all necessary efforts to carry out the plan for building railways linking the north and the south of the Korean Peninsula, Russia and Europe. (“DPRK-Russia Moscow Declaration”)

Russia took the lead with ISR. In March 2001, the Russian Railway Ministry announced its plan to modernize the railway stretch from Russia’s Khasan station to North Korea’s border with South Korea. As part of the ISR project, Moscow upgraded $240 \mathrm{Km}$-long section from Ussuriysk to Khasan in October 2002. For the TKR project, North Korea chose the route on the eastern coast (Geumgangsan-Anbyon section) over the southern route connecting Pyongyang and Wonsan. (See Figure I)

$<$ Insert Figure 1 here $>$

Russia intended to link the lines between Valdivostok and Chongjin on North Korea's east coast in the first phase and then connect the railway to South Korea. As a pilot project, Russia planned to renovate the 54-km railroad section from Khasan to Rajin and modernize the pier 3 terminal of the port of Rajin. The port of Rajin is located in the northeastern corner of North Korea, $56 \mathrm{~km}$ from the Russian border. It is an ice-free port with a deep-water approach. RasonKonTrans, a joint venture between Russian Railways (RZD) and North Korea's Rajin Port, was launched in 2008 to reconstruct the railroad link between Khasan and Rajin and modernize the Rajin port. The joint venture is 70 per cent controlled by Russia and 30 per cent by North Korea. The project was intended to develop

\footnotetext{
${ }^{2}$ Ahn ByungMin at the Korea Transport institute, Telephone Interview, January 6, 2017, Seoul.
} 
Rajin into a logistics hub for sending cargo from South Korea to Europe through Russia’s TSR. The joint venture also included the construction of coal and container terminals at the Rajin port. Russia's keen interest in Rajin is also motivated to counter China's growing economic influence in North Korea. China is building a four-lane highway connecting Hunchun to Rajin. At the end of 2005, a private company from Jilin, China, leased pier 1 of the Rajin port for 10 years (2008-18). North Korea gave Russia the right to use Pier 3 for 50 years.

In September 2013, a 54-kilometer, double-track railroad section linking Khasan and Rajin (Rason) was reopened after five years of renovation. RasonConTrans obtained the right to use the line for 49 years. The 9 billion Rouble (US \$283 million) construction project involved relaying 54 km of dual-gauge (1520mm and 1435mmgauge) track and the refurbishment or replacement of 18 bridges, 12 culverts, and three tunnels ("North Korea Russia Rail link Reactivated”). In July 18, 2014, the new cargo terminal at the port of Rajin opened. The terminal is capable of handling five million tonnes of freight a year. With the opening of the terminal, cargo will be delivered to the Rajin port by rail from Russia via the Khasan-Rajin railway section. At first, coal and other bulk cargo will be handled. In the future, cargo will include containers (up to 100,000 TEU a year).

During his state visit to Seoul in November 2013, Putin pitched for his ISR project: “This [ISR] project, if accomplished, will help make a great contribution to the establishment of peace and stability on the Korean peninsula” (“Putin lobbies for 'Iron Silk Road’ via N. Korea”). During the visit, Seoul agreed to participate in the RasonConTrans joint venture project. South Korea's plan was to form a consortium consisting of Posco, Hyundai Merchant Marine, and Korail which would acquire half of the 70 percent stake that Russia held in the joint venture. If South Korea's consortium would join RasonCon Trans, it would participate in running the railroad and constructing the Rajin port. ${ }^{3}$

To test the feasibility of using the Rajin port for exports, Moscow, Seoul, and Pyongyang carried out a pilot project in 2014-15, in which POSCO would import coal from Russia through North Korea’s Rajin port. In December 2014, the first shipment of 45,000 tons of bituminous coal from West Siberia was carried from Russia’s Khasan to North Korea's Rajin via the 54 km long railroad section and then shipped to South Korea’s port of

\footnotetext{
${ }^{3}$ Kim Kyung Sool, Senior Research Fellow at Korea Energy Economics Institute, Personal Interview, July 10, 2014, Anyang-city, Korea.
} 
Pohang. ${ }^{4}$ In April 2015, the second shipment of 140,000 tons of bituminous coal was made from West Siberia to Korea's three ports. In November 2015, the third shipment of 120,000 tons of bituminous coal was made from West Siberia to Korea's two ports, Pohang and Gwangyang through Rajin. In the following month, a container ship carrying Chinese natural spring water arrived in Busan from Rajin (Song 2015).

Should the project prove cost-effective, the South Korean consortium would hold further talks with the Russian side for a formal contract. According to South Korea’s Unification Ministry estimation, the Rajin to Khasan logistics project can reduce the cost by 10-15 per cent. POSCO currently imports about 2 million tons of Russian coal per year from Vladivostok. The Russian side, however, refused to provide the essential data relating to transportation costs. As a result, POSCO was unable to conclude if the project would be economically profitable. ${ }^{5}$ In this pilot project, Russia paid for the costs incurred for the use of the Rajin terminal and of the Khasan-Rajin railroad, but did not reveal the amount of the costs. Without this information, it will not be feasible to verify South Korean government's position that importing coals from Rajin to Pohang would result in up to 15 per cent cost reduction. Furthermore, Russia did not reveal the asset value of RasonKonTrans which makes it difficult for the Korean consortium of three corporations to negotiate for joining the joint venture (Cho 2014).

South Korea hailed the test run as the first step to trilateral economic cooperation as part of its Eurasian Initiative. The spokesman of South Korea's Unification Ministry pledged South Korean government support for the trilateral economic project. (Lee 2014). The Unification Ministry of South Korea maintained that the Rajin-Khasan project would be exempt from the May 24th Measure, which included economic sanctions imposed on the North after the latter carried out a deadly torpedo attack on a South Korean warship in 2010. The Park government pushed

\footnotetext{
${ }^{4}$ South Korea is not the only destination for Russia's coal exports through the Rajin port. In March 2014, first shipments of the Kuzbass coal from the stations of the Western-Siberian railway transported by rail to Rajin. The coal (8,840 tons) was then shipped out to the ports of Shanghai, Lyanyungan, Guangzhou in China. Russia is expected to export coal, coke, iron ore to Southern and Southeastern coastal provinces of China at prices comparable to the prices delivered from Russian ports. See Russian Railways Logistics (2014).

${ }^{5}$ Oh Youngdal, Team leader, Direct Control of CEO Value Management Department at POSCO, Personal interview, July 10, 2014, Seoul.
} 
for the Rajin-Khasan project as part of its “Eurasia Initiative” which was intended to boost Seoul’s economic growth by establishing a Eurasian system of transport and energy networks and at the same to reduce tensions with North Korea and establish the infrastructure for a unified Korea. ${ }^{6}$ Russia also underlined the significance of this project. Foreign Minister Lavrov stated that success of this trial run might lead to the implementation of the trilateral economic projects involving railways, gas, and electricity: "Based on the results of this pilot delivery, we will start working to connect the Trans-Korean Railway with the Trans-Siberian Railway. . . .If it succeeds, our partners from the DPRK would be ready to consider other trilateral projects, including the delivery of Russian gas across North Korea to South Korea and a similar route for electricity” (Russian Ministry of Foreign Affairs 2014). Moscow has been keen on the trilateral economic project expecting that it would facilitate the economic development of its Far Eastern region and lead to its enhanced influence and stature in Korea. North Korea would also stand to benefit economically since it would earn hard currency in the forms of rent and transit fees.

In October 2014, Russia and North Korea signed a separate joint railway agreement in which the former would renovate North Korea’s dilapidated railway networks in exchange for the latter’s access to the North’s mineral resources. Russia’s private investors are expected to spend \$25 billion for modernizing more than 3,000 kilometers of the North's railroads over 20 years (Kim, Yonho 2014). The project should connects the two stations in the Jaedong coalfields in the North's South Pyongan province and to the country's west coast port of Nampo. A group of Russian firms, including Mostovik, would participate in the joint venture dubbed Pobeda (victory in Russian). Until then, the only Russian investment in North Korea was RasonKonTrans. This second railway project involved a western line (Jaedong-Kangdong-Nampo) which would connect areas producing coal and cement to Nampo port. (See Figure 2). After Mostovik went bankrupt, the project was suspended temporarily. But another Russian company took it over and the project is making a slow progress.

On January 6, 2016, Pyongyang conducted a nuclear weapons test for the fifth time in violation of UN Security Council (UNSC) resolutions. This time, the North claimed that it had successfully tested a hydrogen bomb. On February 7, the North in another act of provocation test fired a long-range missile. In response, Seoul took a

\footnotetext{
${ }^{6}$ Park Kichang, European Division Director, European Affairs Bureau, Korean Ministry of Foreign Affairs, Personal interview, July 30, 2014, Seoul.
} 
series of punitive measures against Pyongyang. In February, Seoul discontinued the operation of the Gaesung Industrial Complex, the only remaining inter-Korean economic cooperation project through which South Korea's 125 manufacturing companies hired 50,000 North Korean workers. In March, Seoul indefinitely suspended the Rajin-Khasan project pending Pyongyang's denuclearization. These actions were part of South Korea's independent sanctions in addition to the latest U.N. Security Council sanctions. Moscow, however, continuously pursued the Rajin-Khasan project regardless of North Korea’s reckless behavior and UNSC's latest sanctions against the North. Russia points out that the trilateral logistics project is not subject to UNSC resolution 2270. In fact, at the insistence of Russia, sanctions contained in UNSC resolution 2270 excluded exports of Siberian coal through Rajin. Russia’s position as regards UNSC resolution 2270 is indicative of its foreign policy priorities and its approach to North Korea's nuclear question. Unlike the U.S., Russia does not consider North Korea’s nuclear programs an immediate and grave threat to its security. Rather it places a top priority on the Rajin project. Russia share the US goal of denuclearizing the Korean peninsula but favors a political approach rather than a forceful one. In this context, the Kremlin often chastises the U.S. for escalating tensions simultaneously condemning North Korea nuclear provocations.

In September 2016, Alexander Galushka, Russia’s minister for the development of the Russian Far East, invited Seoul to join trilateral economic cooperation with Moscow and Pyongyang insisting that economic ties rather than sanctions would pave the road to stability on the Korean peninsula (Interfax 2016). Without Seoul’s participation, Russia continued the Rajin-Khasan project, shipping Siberian coal to China and Southeast Asia from Rajin.

$<$ Insert Figure 2 here $>$

\section{Gas Pipeline}

The construction of a gas pipeline running from Russia’s Far East to South Korea through North Korea is another trilateral project touted by Putin. This project was expected to facilitate economic development of Russia's East Siberia and Far East and help Seoul secure a long-term, stable supply of energy. South Korea's interests in 
trans-national gas pipeline date back to the late 1980s when Jung Joo-Young, the founder of the Hyundai Group, explored the possibility of a long-distance gas pipeline from Sakha Republic to South Korea via North Korea. In the wake of the first inter-Korean summit in June 2000, North and South Korea for the first time discussed the pipeline routes from China and Russia to South Korea via North Korea. At the time KOGAS proposed that the DPRK look into the possibility of laying a gas pipeline from the Kovykta gas field through North Korea. In addition to Sakha and Kovykta, South Korea also explored the option of pipeline gas from Sakhalin Islands. In November 2003, RP, CNPC (China National Petroleum Corporation), and KOGAS signed an International Feasibility Study Report about the project. The Report concluded that the gas and condensate project was technically feasible and economically viable. The planned 4,887-km-gas-pipeline, would link the Kovykta gas field in Russia’s East Siberia to cities of Shenyang, Beijing and Dalian in China and will finally reach Pyongtaek in ROK through a sub-sea pipeline. The trilateral talks between RP, CNPC, and KOGAS, however, halted following the appointment of Gazprom by the Russian government to handle all gas exports to Asia. In September 2004, President Roh Moo-Hyun and President Putin agreed to actively boost economic cooperation and push joint development of oil and natural gas fields. Stateowned KOGAS in 2008 would start buying 1.5 million metric tons per year of liquefied natural gas (LNG) from Sakhalin Energy under a 20-year contract (Oil Daily 2005). In September 2009, negotiations to import Russian natural gas through North Korea were suspended due to strained inter-Korean relations. South Korea preferred importing LNG by ship directly from Russia (North Korea Economy Watch 2015).

In 2011, Gazprom began to discuss the gas project with North Korea (Gabuyev 2011). During his meeting with President Dmitry Medvedev in August 2012, Kim Jong-Il agreed to allow a Russian gas pipeline to pass through his country to South Korea for an annual fee of US \$100 million. At the time, the two leaders agreed to form working groups for the development of economic cooperation in various fields, including gas and railroad. Earlier in September 2011, Gazprom signed a memorandum of understanding with its South Korean counterpart to start construction of the pipeline in 2013 and to ship gas through the pipeline beginning in 2017. South Korean officials, however, downplayed the significance of this timetable, while pointing out that it was unrealistic and not legally binding (Yonhap 2012). North Korea's continuing nuclear crisis and mutual distrust between the two Koreas remained the main obstacle to the gas pipeline plan.

The 1,800 Km Sakhalin-Khabarovsk-Vladivostok natural gas pipeline project was launched in July 2009 and completed in September 2011 at the cost of \$11 billion ('Sakhalin - Khabarovsk - Vladivostok Gas Pipeline’) 
(See Figure 3) The gas pipeline would cut down utilities costs in the Russian Far East as a substitute for expensive coal and petroleum at the regional power and heating plants. The gas pipeline is also part of Russia's gas export route to Northeast Asian countries such as South Korea, China, and Japan. The gas pipeline if extended to the Korean peninsula would run 1,100 Km, and $700 \mathrm{Km}$ of it passing through North Korea. Construction of the North Korean part of the pipeline project would cost $\$ 2.5$ billion. Russia proposed to supply South Korea with 12 bcm of gas through this pipeline. Currently, Gazprom supplies 1.5 million tons of LNG to South Korea per year (Interfax 2011).

$<$ Insert Figure 3 here $>$

At their summit meeting in Ulan Ude in November 2011, President Lee Myung-Bak and President Medvedev agreed to work closely together for the pipeline project (Kremlin 2013). Although Moscow and Seoul repeatedly expressed their support in principle for a trilateral gas pipeline project, both sides harbored serious doubts about its feasibility. When Kim Sung-Hwan, Foreign Minister of South Korea, visited Moscow in August 10, 2011, both Seoul and Gazprom expressed strong doubts about the implementation of the gas pipeline project in view of heightened tension between the two Koreas and Pyongyang’s possible shut-down of the pipeline in time of crisis. By the end of 2011, doubts in Seoul on the gas pipeline project grew even stronger. Wi Sung-Lac, ROK's Ambassador to Russia, stated in February 2012 that the gas pipeline project was at the discussion stage (The Daily NK website 2012). Moscow was holding bilateral talks on this issue separately with South and North Korea, and no concrete agreements were reached.

In April 2014, the State Duma, Russia’s lower house, ratified a 2012 agreement to write off 90 percent of North Korea’s debt. As of September 2012, the total debt owed by the North to Russia amounted to $\$ 10.96$ billion. The remaining debt ( $\$ 1.09$ billion) should be paid back during 20 years in equal installments every six months. The debt repayment may be used to finance economic projects in North Korea, including the proposed gas pipeline and railway renovation in North Korea. It is likely that the Kremlin decided to forgive most of North Korea's debt in an effort to boost bilateral economic cooperation and strengthen bilateral political ties. Following Kim Jong-Un’s special envoy Choe Ryong-Hae’s visit to the Kremlin in November 2014, Russian Foreign Minister Sergey Lavrov 
observed that North Korea was ready to consider projects to transport Russian gas and electricity through its territory to South Korea. He was hopeful that the first shipment of coal from Russia to South Korea via the Rajin port would pave the road to other trilateral cooperative projects (Tass 2014).

After long delays and frequent policy reversals, Russia began to implement large scale, multinational energy projects in Northeast Asia. The first stage of the 4,188 km long Eastern Siberia-Pacific Ocean oil pipeline was completed in May 2009, and in January 2011, Russia begun oil shipments to China through the line. The second stage of its construction began in December 2012. The construction of the 1,800 km Sakhalin-KhabarovskVladivostok gas pipeline was completed in 2011. In May 2014, Russia signed a \$400 billion gas contract with China. In the deal, Moscow agreed to supply Beijing with 38 bcm of natural gas annually for 30 years through pipelines into eastern China from fields in eastern Russia (Perlez 2015). Six months later, Russia’s Gazprom and China's CNPC signed a framework agreement on gas supply. This deal stipulated that_Russia would supply through pipelines 30 bcm of gas a year to China at \$284 billion (Yep 2014). Russia’s ambitious energy projects and their consummations in long-term contracts are ascribable to Putin’s personal interest in energy policies and shift in geographic priorities from Europe to the Asia-Pacific.

Putin has long envisaged delivering pipeline gas to South Korea through North Korea. This option of gas delivery has the advantages of low costs and possibly inter-Korean economic cooperation. To bypass North Korea, Russia may construct an undersea gas pipeline in the East Sea (or Sea of Japan) from Russia to South Korea. In an interview with South Korean TV network in November 2013, Putin stated that an undersea gas pipeline was doable but difficult. An undersea pipeline from Vladivostok to South Korea may be 650-900 Km long. Sea depths along the route are deep, reaching 3,000 meters in some places. Furthermore, the ocean floor along the route is irregular making the construction even more challenging. Putin said that the Russian side might proceed with this route if it could secure long-term delivery contracts. A third option for delivering gas to South Korea will be in Liquefied Natural Gas (LNG) (Interfax 2013). Gas prices in the form of LNG, however, are 3 times those from a natural gas pipeline. Gazprom favors the LNG option. So does its Korean counterpart KOGAS. Currently, South Korea ranks the $2^{\text {nd }}$ in the world as gas importer, and 70 percent of its energy supply depends on imports. The country will need to import increasing volumes of natural gas for its economy. KOGAS is mostly interested in importing gas from the Sakhalin fields, but not from East Siberia (Kovykta and Sakha). Russian gas from Eastern Siberia is of low quality 
and not suitable for South Korea’s domestic consumption. Like Gazprom, KOGAS also prefers LNG imports from Russia and considers a natural gas pipeline an intermediate- or long-term project. ${ }^{7}$

\section{Electric Gridlines}

Exporting its surplus electricity to Seoul via Pyongyang through a unified electric grid system is a third trilateral economic project espoused by Moscow. For years, North Korea has been suffering from serious electric shortages. Due to outdated equipment and lack of spare parts and fuel, North Korea's power stations are running at 20 percent of their generating capacities. The country can satisfy only 40 percent of its electric needs. As a result, factories cannot operate in full capacity, street lights are not lit at night, and apartment buildings remain without electricity most of the day in North Korea. In the early 1990s, North Korea constructed a 5-MW nuclear reactor in Yongbyun ostensibly to generate electricity. In the wake of the 1994 US-North Korea Agreed Framework, the Korea Energy Development Organization (KEDO) - an international consortium consisting of the US, South Korea, Japan, and EU - was formed to provide two light-water reactors to the DPRK by 2003 in exchange for the North's freezing its nuclear program. The two nuclear reactors would provide two million kilowatts of power a year. The KEDO project, however, came to a halt as disputes over North Korea’s nuclear programs intensified.

After the collapse of the KEDO’s light-water project, Russia offered to supply North Korea with electricity and gas as a substitute for nuclear energy. In November 2001, Russia announced its willingness to export electricity from its Far Eastern region to North Korea. In October 2003, energy experts from South Korea and Russia agreed to build a tripartite electrical power network linking Vladivostok and South Korea through North Korea. By the end of 2003, North Korea and Russia agreed to link their countries' electrical power lines and discussed the construction of electrical power lines connecting Vladivostok to North Korea’s Chongjin.

In July 2004, Sergei Darkin, then Governor of the Maritime Province, stated in an interview that Russia was completing its plans to export excess electricity from Russian hydroelectric dams to the two Koreas: 'We are building energy transmission lines to the North Korean border. . . [if President Putin] gives us the task of transmitting energy to North Korea next year, we will be ready to do that'(Brooke 2004). Russia's Bureyskaya

\footnotetext{
${ }^{7}$ Yoo Moon-Jong; Kwag, Seong-Seup, Russia Project Team at KOGAS, Personal interview, July 22, 2014, Seoul.
} 
hydroelectric power station in Amur Region, upon completion of its six generating sets, would produce sufficient electricity that would meet the Russian Far East's needs and export electricity to North Korea. At the Russia-North Korea Intergovernmental Commission meeting held in March 2007 in Moscow, the two sides discussed the project of building power lines between Vladivostok and Chongjin (Interfax 2007).

Russian energy company RAO Energy System of East, a subsidiary of state-owned RusHydro, announced in February 2015 a plan to export 200 megawatts of electrical power to North Korea starting in 2016 and to South Korea via North Korea in the long run. RAO is constructing a gas-fired thermal plant in Vladivostok which is expected to be completed in 2015. Excess electricity produced by this plant would be sent to Rason Special Economic zone (SEZ). Electrical grids from Russia’s Khazan region to the North Korean border are under construction. North Korea, on its part, agreed to build the converters necessary to change the power from the Russian 50Hz to the DPRK's 60Hz. Two questions about this project remain. First, it is not clear who will pay for electric bills. Second, since RAO is known to have financial problems, it may not be able to follow through on the trilateral electric power project (Byrne 2015).

North Korea is keen on Russia’s proposed electricity project. At a conference dealing with energy-sharing issues in June 2004, North Korean officials agreed to provide by August basic data on its electric power system to the Korea Electrotechnology Research Institute, a South Korean government research group. In August 2011, Kim Jong-il visited the 139-meter Bureya dam during his official visit to Russia (EIU Views Wire 2011).

South Korea is interested in importing electric energy from Russia’s Far East. South Korea's demand for electric power is on the rise, but its capacity to meet the needs is limited. It is becoming increasingly difficult to find spots for new power plants in the crowded country and residents are vehemently opposed to having a new power plant in their neighborhood. Stable supply of electric energy from Russia at a reasonable price may provide a solution to South Korea's electric energy problem. Russia already has the experience of building electric power plants in a dozen countries including Finland.

In 2006, Russia and the ROK signed an MOU on trilateral economic cooperation in electric power. In 2009, the two countries began their joint research for electric power cooperation. This project, however, was suspended in 2010 following the sinking of a South Korean warship Cheonan by a North Korean torpedo. South Korea has done some preparations as regards sharing Russia’s electric power. In November 2013, Russia’s mining, 
metals and energy group, Korea Electric Power Corporation (KEPCO), and Skolkovo Institute of Science and Technology (Skoltech) signed a Memorandum of Understanding to conduct a joint research into the integration of power systems of Russia and South Korea. The research was a part of the NEAREST project (North East Asian Region Electrical System Ties) which resulted from an APEC initiative to integrate power systems of North East Asia countries (China Weekly News 2013)

For the implementation of the electricity sharing project, some technical problems need to be resolved. The electric power systems of Russia and South Korea are incompatible. To import electric energy from Russia, AC (alternating current) has to be transformed into high-voltage direct current (HVDC) for long-distance transmission. After receiving electricity, South Korea needs to convert the power from Russia's $50 \mathrm{~Hz}$ to its $60 \mathrm{~Hz}$ for domestic consumption. South Korea currently does not have the technology for HVDC transmission, but is expected to acquire it in 5-6 years. Initially, Russia proposed sending electricity from hydro-power plants in Amur region, but recently is talking about sending it from thermal power plants in Vladivostok. The price of Russian electricity in the Far East is about 30 percent cheaper than South Korea's. If all costs are accounted for, electric power imported from Russia may be supplied at about the same price as South Korea's electricity or slightly below it. The price will of course depend on negotiations. Russia, however, has yet to offer the price for its electricity. ${ }^{8}$

The proposal to supply Russia's surplus electricity to the two Koreas via electric gridlines is still at the conceptual stage. Russia has yet to provide detailed information, including the price. If South Korea suffers serious shortages in electricity in the future and if the price is right, Seoul may be more susceptible to the idea. For now, no consultations or negotiations are under way. Among the three economic projects, this one is the lowest in priority and least likely to be implemented.

\section{Assessment}

Would the proposed trilateral economic projects be technically feasible and economically cost effective? The pilot projects of the Khasan-Rajin railroad modernization in 2013 and of Russia’s coal export to South Korea through Rajin in 2014-15 demonstrated that three-way economic projects in energy and transportation was doable.

\footnotetext{
8 Jeong Kyu-Won, Senior Manager at Korea Electric Power Corporation, Personal interview, July 15, 2014, Seoul.
} 
The pilot projects indicated that trilateral economic cooperation would be feasible under the right conditions. But the conditions are far from right. A major stumbling block is North Korea’s obsolete railway infrastructure. To link the TSR with the TKR, Pyongyang's dilapidated railway networks need upgrading. The North's railroad system is in a deplorable state and needs extensive and costly modernization that may take 20 years or more. Currently, trains in North Korea travel at about 20 miles per hour due to poor conditions of roadbeds, bridges, and tunnels. Likewise, before Russia’s electric energy is transmitted to South Korea via North Korea, the North’s electric grids must go through extensive update and repairs.

Russia would have a lot to gain from the gas pipeline running across the Korean peninsula. In September 2007, Russia adopted the Eastern Gas Program for an integrated natural gas production, transit, and supply system in East Siberia and the Far East. Russia intends to increase its energy exports to Asia especially after it faces economic sanctions from EU and the U.S. in the wake of the recent armed conflicts in Ukraine. For years, Russia has sought to diversify its markets for gas supply from Europe to East Asia, and a gas pipeline from Vladivostok to Seoul would be a right step in this direction. Furthermore, a gas pipeline contract with South Korea would strengthen Russia's bargaining position vis-à-vis China and Japan for future energy contracts. Since the Soviet era, Russia has sought to join the East Asian community as a full-fledged member. The trilateral projects would help Russia integrate into the vibrant economy of East Asia and might bring an economic boon to Russia’s Far East.

Seoul and Pyongyang may reap economic benefits from ISR as well. It might strengthen South Korean businesses' competitive edge by reducing shipping costs and shortening transportation time for their European trade. Currently, South Korea sends most of its goods to Europe by sea - around India and through the Suez Canal. Inefficiency, lack of transparency, red tapes, and outdated facilities and equipment on the part of Russia and North Korea, however, would pose real challenges to efficient operations of ISR. A trans-national gas pipeline running from Russia’s Far East to the Korean peninsula would secure a long-term gas export for Moscow and provide Seoul with a steady, long-term gas import probably at a cheaper price. Likewise, electric gridlines running from Russia’s Far East through North Korea to South Korea would help stabilize South Korea’s electric energy supply. North Korea stands to benefit from these deals as well. The North would earn \$100-\$200 million per year in transit fees and its energy shortages would be alleviated after receiving electric power and gas as part of the deals.

Moscow contends that trilateral economic projects will create the "right" condition for dialogue, mutual trust, and peace process on the Korean peninsula. The Korean question, especially North Korea's nuclear issue, is 
political in nature and calls for a political solution. As evidenced in history, economic cooperation will not spill over into political cooperation and integration. During the Kim Dae-jung and Roh Moo-hyun governments (1998-2008), South Korea rapidly expanded its economic transactions, personal interactions, and cultural/sports exchanges with North Korea. Nevertheless, tensions continued and crisis recurred on the Korean peninsula. When political differences continue unabated between two countries, one is often tempted to use economic interdependence as a weapon. A minimum level of mutual confidence and trust indeed will a prerequisite for the trilateral economic cooperation.

In an interview with Korea Herald, Konstantin Vnukov, then Russian Ambassador to Seoul, stated that Russia would need 'guarantees for judiciary obligations' from the North Korean government before a gas pipeline project proceeds. He added: "Without this it would be impossible to invest money in this huge project." (The Korea Herald 2011). Whether a legal document will actually ensure North Korea’s compliance with an international contract is a moot question though. Alexander Vorontsov, a Russian expert on Korean affairs, predicted that trilateral projects would facilitate improved political atmosphere on the Korean peninsula contributing security and stability in Northeast Asia. He further argued that the North would not risk losing a handsome reward in transit fees by shutting down a gas pipeline to the South (Vorontsov 2012). In world politics, political considerations most often trump economic calculations, and North Korea's past behaviour is a good testimony to this fact. When it comes to security, the South cannot afford relying on the North’s good will alone.

\section{Conclusion}

Since 2000, Russia under Putin has been steadfast in pushing for trilateral economic cooperation among Russia, South Korea, and North Korea. The rationale is that such cooperation will bring economic benefits for all and lead to the 'peace dividend' of inter-Korean cooperation and reconciliation. The Kremlin has been surprisingly consistent and enthusiastic about this policy even when the prospects for its implementation were grim. Most of all, on-going North Korea’s nuclear crisis and sustaining tensions on the Korean peninsula makes the trilateral economic cooperation virtually unthinkable.

The question then is why Russia has been so stubborn with it. The answer appears to lie in Russia’s desire to create a multipolar world order and to be recognized as a central player in it after destroying U.S. dominant order. The behaviour pattern consistent with the desire is determined largely by the power structure of the international 
system. SR postulates that a unipolar structure of the international system is not likely to last long since there is a strong tendency for major powers to balance the hegemon (the US). As early as 1993, Waltz predicted that the US dominant international system would be replaced by a multipolar one. Russia's behaviour pattern as regards North Korea's nuclear issue and the trilateral economic projects indicates that its foreign policy is geared toward balancing the US. Russia's refusal to impose harsh sanctions or take measures to destabilize the Kim Jong-Il regime may be interpreted as its balancing the U.S. In its endeavour to forge a multipolar world order, Moscow seeks a trilateral alignment of Russia, China, and India, develops ties between BRIC (Brazil, Russia, India, and China) countries, and strengthens the Shanghai Cooperation Organization (SCO). At the same time, the Kremlin will continue to develop bilateral ties with countries like China, North Korea, Venezuela, Syria, and Iran. Russia more than once applied its economic leverage (energy resources) for extract political concessions from target states. The Kremlin might use the two Koreas' dependence on its energy resources as a tool for coercive diplomacy. If the goal of supplying South Korea with 10 bcm of gas annually is achieved, South Korea's dependence on Russian gas would increase from 6 to 30 percent. The gas and electricity projects would deepen Seoul’s energy dependence on Russia, making Seoul vulnerable to Russia's political pressures. When Seoul and Pyongyang become economically dependent on Moscow, Moscow's influence in Korea should increase.

The trilateral economic projects appear to be sound economically. The bigger question, however, is whether all the three countries involved share the political will to do it. Moscow is eager, Pyongyang is willing, but Seoul is reluctant. According to Russia’s senior officials and businessmen, Moscow and Pyongyang are ready for the trilateral projects but Seoul refuses to give its commitment (Kim, Young-Hee 2014). Pyongyang has earned a welldeserved reputation as a rogue state known for its untrustworthy, belligerent, and reckless behaviour. South Korea's distrust toward the Kim Jong-Un regime is deep-seated.

For now, the three-way economic cooperation is beyond grasp. But it may be implemented under changed circumstances. First, political resolution of North Korea’s nuclear crisis may facilitate its implementation. To date, North Korea’s nuclear and missile programs remain the main stumbling block barring inter-Korean cooperation and the trilateral economic cooperation. As the war of words between Donald Trump and Kim Jong-Un continues and no diplomatic negotiations are currently underway, this scenario is unlikely. Second, the removal of Kim Jong-Un from power and the arrival of a reform-minded political leader in Pyongyang may create the right condition. Into his sixth year in power, Kim Jong-Un appears to have a firm grip on power, and there are no signs that he may fall from 
power through internal upheavals. Third, political reconciliation, economic cooperation, and personal/cultural/sports exchanges between Seoul and Pyongyang will certainly brighten the prospects for the trilateral economic cooperation. The progressive government of Moon Jae-In may find a common ground with the North in the desire to prevent a second Korean War. Just like Kim Dae-Jung continued his “sunshine policy” toward Kim Jong-Il despite and because of G.W. Bush's hardline policy toward the North, it is thinkable although very unlikely at the moment that Moon Jae-In may have a major political breakthrough with Kim Jong-Un. Given the frozen relationship between Seoul and Pyongyang, this scenario is as much unlikely as the others. 


\section{References}

Brooke, James (2004) Russia Wants to Supply Energy to North Korea, New York Times, 4 July 2004.

Byrne, Leo (2015) Russia and the DPRK could cooperate on electricity, though South Korean input looks unlikely, NKnews.org, February 2, 2015, at http://www.nknews.org/2015/02/wired-up-north-korea-looks-to-russia-forelectricity/ Accessed 11 February 2015.

China Weekly News (2013) En+ Group; En+, KEPCO and Skoltech to Study Integration of Power Systems of Russia and South Korea, 26 November 2013.

Cho, Sung-Ho (2014) Russia’s Motive behind the Pilot Project, Dong-A Ilbo, 22 November 2014.

Choi, He-suk (2013) Park seeks ‘Eurasia Initiative’ to build energy, logistics links, The Korea Herald, October 18, 2013, at http://www.koreaherald.com/common_prog/newsprint.php?ud=20131018000620\&dt=2. Accessed 22 October 2013.

Cohen, Stephen F. Obama’s Russia ‘Reset’: Another Lost Opportunity. Nation, 20 June 2011:11-18.

DPRK-Russia Moscow Declaration (2015) at http://www.korea-dpr.info/lib/204.pdf. Accessed 5 February 2015.

EIU ViewsWire (2011) North Korea politics: Kim Jong-il's Russia visit has mixed results, EIU ViewsWire, 1 December 2011

Gabuyev, Aleksandr (2011). ‘They Will Use Gas To Pacify North Korea: Gazprom Is Prepared To Join in Solving the DPRK Nuclear Problem', Kommersant Online, 22 August.

Hydrocarbons-technology.com (2015) Sakhalin - Khabarovsk - Vladivostok Gas Pipeline, Russia, Hydrocarbonstechnology.com, available online at http://www.hydrocarbons-technology.com/projects/sakhalin-pipeline/. Accessed 7 February 2015.

Interfax (2007) Russia, North Korea Discussing Energy Exports, Interfax, 23 March 2007.

Interfax (2011) Gas Pipelines \& Transportation: Gas transit from Russia could earn North Korea \$100 mln annually, Interfax, 23 November 2011. 
Interfax (2013) Putin: Russia needs price, volume guarantees before building gas pipeline to Korea, Interfax, 12 November 2013.

Interfax (2016) Russia invites South Korea to join Khasan-Rajin railway project - Galushka, Interfax, September 1, at http://www.interfax.com/newsinf.asp?id=698179. Accessed 18 March 2017.

International Crisis Group (2008) North Korea-Russia Relations: A Strained Friendship, Crisis Group Asia Briefing, $N^{\circ} 71$, December 4, p. 12, at http://www.crisisgroup.org/home/index.cfm?id=5198. Accessed 24 October 2008.

Kang, Yong-Soo (2000) The Potential to supply Natural Gas from Sakhalin Project to Korean Market, a paper presented at the $4^{\text {th }}$ Annual Conference on Sakhalin Oil and Gas organized by IBC Global Conferences Ltd, London, 20-21 November 2000.

Kim, Yonho (2014) Russia, North Korea Strike Deal: Improved Railway for Mineral Resources, Voice of America News, November 8, at http://www.voanews.com/a/russia-to-overhaul-north-koreas-railway-in-return-formineral-resources/2513493.html. Accessed 15 March 2017.

Kim, Young-Hee (2014) Embrace of Moscow and Pyongyang, JoongAng Ilbo, 5 December 2014.

Kremlin (2013) Putin’s Press Statement after Russian-Korean Summit, Moscow, 13 November 2013 at http://en.kremlin.ru/. Accessed 13 May 2014.

Lee, Moosung (2016) The EU, regional cooperation, and the North Korean nuclear crisis. Asia Europe Journal 14: 401-415.

Lee, Sang Yong (2014) South-North-Russia Trial Project Seen as 'First Step, DailyNK, December 2, at http://www.dailynk.com/english/read.php?num=12627\&cataId=nk00100 http://famagusta-gazette.com/russiankorea-relations-acquiring-new-quality-dprk-ambassador-to-russiap26170-69.htm. Accessed 5 December 2014.

Mankoff, Jeffrey (2009) Russian Foreign Policy: The Return of Great Power Politics. Lanham, MD. Rowman \& Littlefield. 
Nation, Craig (2012). Reset or Rerun? Sources of discord in Russian-American relations. Communist and PostCommunist Studies. 45(3-4): 379-38.

North Korea - Russia rail link reactivated (2013) International Railway Journal, Issue 11, November 2013.

North Korea Economy Watch (2015) Russia/North Korea/South Korea: Plan to import Russian natural gas via N. Korea put on hold, North Korea Economy Watch, 30 September 2015 at http://www.nkeconwatch.com/2009/09/29/russia-rok-gas-deal-on-hold/. Accessed 6 February 2015.

Oil Daily (2005) Korea Seeks Russia Gas Deal, Oil Daily, 28 September 2005.

Padden, Brian (2016) South Korea Sanctions Halt Russian Rail Project with North Korea, Voice of America News, March 8, at http://www.voanews.com/a/south-korea-sanctions-halt-russian-rail-project-with-northkorea/3225395.html. Accessed 17 March 2017.

Perlez, Jane (2015) China and Russia Reach 30-Year Gas Deal, New York Times, 21 May, at http://www.nytimes.com/2014/05/22/world/asia/china-russia-gas-deal.html. Accessed 7 February 2015.

Putin lobbies for 'Iron Silk Road' via N. Korea, hopes political problems solved shortly (2014). RT, 13 November 2013, at http://www.rt.com/business/putin-lobbies-iron-silk-seoul-677/. Accessed 10 December 2014.

Russian Ministry of Foreign Affairs (2008) Foreign Policy Concept of the Russian Federation, Ratified by President of the Russian Federation D. A. Medvedev’ on July 12, 2008, at www.mid.ru. Accessed 11 May 2010.

Russian Ministry of Foreign Affairs (2013) Putin’s Press Statement after Russian-Korean Summit, Moscow, November 13, 2013 at http://en.kremlin.ru/ Accessed 13 May 2014.

Russian Ministry of Foreign Affairs (2014) Remarks and answers to media questions by Foreign Minister Sergey Lavrov during a news conference following talks with Special Representative of DPRK leader Choe Ryong Hae, (Moscow) November 20, 2014 in English posted by the Russian Ministry of Foreign Affairs Website on November 24, 2014, at http://archive.mid.ru//brp_4.nsf/main_eng. Accessed 10 December 2014. 
Russian Railways Logistics (2014) Russian Railways Logistics to transport coal through port of Rajin in North Korea to Asia-Pacific, Russian Railways Logistics, April 8, at http://www.rzdlog.com/press/254/ Accessed 5 December 2014, 6 February 2015.

Song, Sang-ho (2015), Rajin-Khasan project enters 3rd test run, Korea Herald, November 17, at http://www.koreaherald.com/view.php?ud=20151117001047. Accessed 11 March 2017.

TASS (2014) Russia’s Lavrov says Pyongyang ready to mull gas, electricity transit to S Korea, TASS, 20 November 2014.

The Daily NK website (2012) South Korean envoy notes advancement in gas pipeline with Russia, North Korea, The Daily NK website, 27 February 2012.

The Institute for Eastern Studies (Kyungnam University) (2011), DPRK Seeks Foreign Capital through Rajin Port Development, NK Brief (10-03-11), at http://ifes.kyungnam.ac.kr/eng/FRM/FRM_0101V.aspx?code=FRM1012_000350. Accessed 22 December 2011.

The Korea Herald (2011) Russia seeks North Korea's 'guarantee' on gas pipeline, The Korea Herald, 23 August 2011.

Vorontsov, Alexander (2012) The Korea-Russia Gas Pipeline Project: Past, Present, and Future, SERI Quarterly, Issue 1, January.

Waltz, Kenneth N. (1993) The Emerging Structure of International Politics, International Security, 18 (2): 32-64.

Waltz, Kenneth N. (2000) Structural Realism after the Cold War, International Security, 25 (1): 5-41.

Waltz, Kenneth N. (1979) Theory of International Politics. Reading, MA: Addison-Wesley Publishing Company.

Yep, Eric (2014) New Russia-China Deal Could Further Hit Natural-Gas Prices, Wall street Journal, November 10, at http://www.wsj.com/articles/new-russia-china-deal-could-further-hit-natural-gas-prices-1415614816. Accessed 7 February 2015. 
Yi, Whan-woo (2016) Seoul suspends Rajin-Khasan logistics project, 8 March at http://www.koreatimes.co.kr/www/common/printpreview.asp?categoryCode=103\&newsIdx=199918. Accessed 17 March 2017.

Yonhap (2012) North Korea reportedly renews commitment to gas pipeline project with Russia, Yonhap, 27 January. 